\title{
Study of effect of electric arc furnace slag on expansion of mortars subjected to alkali-aggregate reaction
}

\section{Estudo dos efeitos do uso da escória de aciaria na expansão de corpos de prova sujeitos à reação álcali-agregado}

\author{
L. SOUZA a \\ luciene__hotmail.com \\ E. R. ZOLETT b \\ eliszolett@hotmail.com \\ R. CARRAZEDO \\ rogcarrazedo@sc.usp.br
}

\begin{abstract}
Alkali-aggregate reaction is a chemical reaction between cement alkalis and some reactive mineral present in some aggregates, leading to concrete expansion and cracking. One kind usually observed and studied in Brazil is the alkali-silica reaction, due to its fast development. There are several methods that are effective to control and mitigate this reaction, and one of them is the partial replacement of cement by mineral additions such as pozzolans like fly-ash, silica fume and slag. In this study, we propose the use of electrical steel slag as a partial replacement of cement, evaluating its effectiveness by NBR 15577:2008, employing different proportions as replacement. It seems that the electrical steel slag, despite its expansive behavior, has been effective in the control of the ASR.
\end{abstract}

Keywords: concrete expansion, alkali-aggregate reaction. alkali-silica reaction, pozzolans, steel slag.

\section{Resumo}

A reação álcali-agregado (RAA) é uma reação que ocorre entre os álcalis do cimento e alguns compostos minerais presentes em determinados agregados, gerando consequências ao concreto, como por exemplo, fissuração. A reação com maiores ocorrências registrada no Brasil é a reação álcali-sílica (RAS), devido à rapidez com que esta ocorre em função das formas minerais reativas envolvidas. Vários métodos estudados já se comprovaram eficazes para o controle desta reação, sendo um deles a substituição parcial de cimento por adições como as pozolanas, dentre as quais podem ser citadas as cinzas volantes e as escórias de origem siderúrgica. Neste sentido, este trabalho tem por objetivo o estudo da utilização da escória de aciaria elétrica como redutor da reação álcali-agregado, sendo desenvolvido com base nas orientações da NBR 15577:2008 Agregados - Reatividade Álcali-Agregado, avaliado para diferentes proporções de substituição parcial de cimento por escória. A escória de aciaria elétrica, uma pozolana não tradicional resultante do processo de produção do aço e de características expansivas, teve êxito ao reduzir a expansão da RAS.

Palavras-chave: expansão do concreto, reação álcali-agregado, reação álcali-sílica, pozolanas, escória de aciaria. 


\section{Introduction}

Alkali aggregate reaction (AAR) is a chemical reaction, which occurs between alkalis from cement paste and some alkaline reactive minerals in aggregates. This reaction form a viscous hygroscopic gel that fills concrete voids leading to damage and reducing the concrete structure life span [1].

There are mainly two types of AAR, alkali-silica reaction (ASR) and alkali-carbonate reaction (ACR), according to the aggregate reactive minerals.

Alkali-silicate reaction can be classified as a specific type of ASR, for its resemblance, because low degree of crystalline silicates or amorphous silicates usually develop alkali-silica reaction while highly crystalline silicates develop alkali-silicate reaction [2]. In this sense, alkali-silicate is observed in opal, amorphous silica, chert or chalcedony, cristobalite or tridymite, natural volcanic and borosilicate glasses, when reacts with cement alkalis and calcium hydroxide. Alkali-silica reaction and alkali-silicate reaction is the most common type of AAR in Brazil, been found in several structures [3] If properly identified, it is possible to minimize the expansion and related cracking. If the aggregate is potentially reactive, replacement may be considered, but cost must be evaluated. Reactive aggregate partial replacement may reduce the potential for expansion. Collins and Bareham [4] partially replaced a reactive aggregate by a porous aggregate, suppressing the expansion through the dilution of alkali concentrations by water absorbed in the porous aggregate. Ducman et al [5] also employed a porous aggregate, yet highly reactive. The porous structure of the aggregate were able to accommodate the gel produced, without causing expansion or cracks in the evaluated mortar bars.

Low-alkali cement can also minimize alkali hydroxide concentration in the concrete pore solution, reducing the potential for expansion. Nevertheless supplementary cementitious materials and external sources of alkalis like deicers and seawater, can contribute to total alkali content of concrete [6]

The expansion reduction may also be attained by chemical additions to the concrete, like lithium compounds. Qinghan et al [7] and Lumley [8] indicate that lithium compounds are effective to inhibit ASR expansion, because it replaces sodium and potassium alkaline ions in ASR gel, densifying it. Notice that, if insufficient lithium is used, the expansion may increase, because lithium compounds may combine with calcium hydroxide as well, producing calcium salts and lithium hydroxide, and increasing hydroxyl ions concentration in the pore solution [9]. Mo et al [10] say that some lithium salts do not release hydroxyl ions in the pore solution as it reacts, leading to best results.
Diamond [11] studied lithium nitrate $\left(\mathrm{LiNO}_{3}\right)$ as a chemical addition, and observed that it did not increase hydroxyl ions in the concrete pore solution, and was able to inhibit ASR expansion. Qian et al [12] observed that lithium hydroxide and lithium salts were effective to suppress ASR but started Alkali-Carbonate Reaction. Silva [13] observed that, beyond a threshold, lithium nitrate had no more influence on the ASR inhibition, and, after a 30 days test, lithium nitrate hold ASR expansion while fly-ash did not.

Mineral additions can be used as supplementary cementitious material and suppress ASR expansion [14]. The most common materials are natural pozzolans, fly-ash, slag, silica fume and rice husk ash. These materials can suppress ASR expansion and also improve some concrete properties, such as permeability, heat resistance (slower conductivity rate), smaller diffusivity (due a denser matrix) and overall durability increase [15].

Munhoz [16] verified that, as blast furnace slag, fly-ash, metakaolin, silica fume are mixed in concrete at increasing amounts, expansion due AAR is reduced. Silveira [17] had similar results with rice husk ash.

Ramachandran [18] stated that mineral additions, such as natural pozzolans, fly-ash, blast furnace slag, silica fume and rice husk ash, would only be effective to inhibit alkali-aggregate reaction according to their chemical composition $\left(\mathrm{SiO}_{2}\right.$ percentage and free alkali ions), to the mixed amount, to the aggregate type (kind of AAR) and to the cement alkali (Sodium, Potassium or Lithium).

Electric arc furnace steel slag is a by-product of steel production, without commercial value and treated like waste, because is made of impurities removed during steel refining operation. Steel slag is mainly composed by lime (calcium oxide - $\mathrm{CaO}$ ) and magnesia (magnesium oxide - MgO), with porous structure where water migrates, reacting with free calcium oxide to form lime slurry (calcium hydroxide $\left.\mathrm{Ca}(\mathrm{OH})_{2}\right)$ that has crystalline structure and twice volume. This volume change leads to stresses, cracks and expansion [19]. Steel slag has high Calcium/Silicate ratio, which means that free calcium oxide has potential to expand when mixed in concrete [20]. Notice that the concrete expansion due AAR is dependent on Ca content [21].

Luxán et al [22] studied the chemical stability and the mineralogical compounds of electric arc furnace slag, stating that the studied slag may be employed as building material. Tsakiridis et al [23] employed steel slag as raw material for the production of cement clinker, showing that the addition of steel slag did not affect cement sintering, the hydration process during production, and had similar mechanical characteristics to usual Portland cement clinker. Qiang and Peiyu [24] also pointed out that the hydration compounds of steel slag are mainly CSH gel and lime slurry, very similar with those of cement.

\section{Table 1 - Cement characteristics - CP V ARI RS}

\begin{tabular}{cccc}
\hline Property & Test method & Results & Limits NBR 15577-4 \\
$\mathrm{Na}_{2} \mathrm{O}$ alkali equivalent* & NBR 14656 & $0.780 \%$ & $(0.90 \pm 0.10) \%$ \\
Free calcium oxide & NBR NM 12 & $1.31 \%$ & - \\
Blaine fineness & NBR NM 76 & $4743 \mathrm{~cm}^{2} / \mathrm{g}$ & $(4900 \pm 200) \mathrm{cm}^{2} / \mathrm{g}$ \\
Autoclave expansion & ASTM C 151 & $0.08 \%$ & $<0.20 \%$ \\
\hline
\end{tabular}


Table 2 - Standard sand characteristics

\begin{tabular}{|ccc|}
\hline Property & Results & Limits NBR 7412:1982 \\
\hline Material passing through 0.075 mm sieve & $0.0 \%$ & $\leq 1.0 \%$ \\
Conglomerate clayey & $0.0 \%$ & $\leq 0.2 \%$ \\
Feldspar content of sieves 2.4 and $1.2 \mathrm{~mm}$ & $2.4 \%$ & $\leq 15.0 \%$ \\
Mica content of sieve 0.3 and $0.15 \mathrm{~mm}$ & $1.9 \%$ & $\leq 2.0 \%$ \\
Organic impurities & $<100 \mathrm{ppm}$ & $\leq 100 \mathrm{ppm}$ \\
\hline
\end{tabular}

Xuequan et al [25] developed a cement made of clinker, steel slag and fly-ash, with cementitious properties close to Portland cement, consuming part of the alkali during hydration, which would reduce expansion due to AAR.

This paper evaluates the electric arc furnace steel slag as partial replacement of Portland cement, instead of raw material for cement clinker production, aiming to suppress alkali-silica reaction, based on the methodology established by the Brazilian standard NBR 15577:2008 [26]. Next, we present the characteristics of the material employed in this study and the techniques to evaluate it. Then, the results are presented, and finally some conclusions are drawn.

\section{Materials and methods}

The materials used were: high early strength Portland cement with improved resistance to sulphate attack (CP V ARI RS), with characteristics presented in Table 1 and following the features required by NBR 15577:2008; fine grained basalt with volcanic glass scattered throughout the rock; Brazilian standard sand - a reference sand that must be used for cement tests, with characteristics presented in Table 2; and electric arc furnace steel slag.

The slag has been crushed and milled in a ball mill into powder form, using only the material passing through $0.075 \mathrm{~mm}$ sieve. Figure 1 presents a sample employing scanning electron microscopy (SEM). One may notice that slag grain shows a round form, with particle size under $10 \mu \mathrm{m}$, but most of it has size under $3 \mu \mathrm{m}$. Figure 2 , obtained with the aid of a laser diffraction particle size analyzer, shows that the particle size distribution of the slag is close to particle size distribution of the cement, meaning that the slag can be used as a mineral addition.

To identify the composition of the slag, an X-ray diffraction was carried out. The main compounds present were periclase (magnesium oxide), quartz (silicate), lime (calcium oxide), alkalies (potassium and sodium), dolomite $\left(\mathrm{CaCO}_{3} \cdot \mathrm{MgCO}\right)$ and calcite $\left(\mathrm{CaCO}_{3}\right)$, that can be verified through the diffractogram of Figure 3.

Table 3 shows the slag chemical composition obtained by X-ray fluorescence spectrometer, while Table 4 shows its apparent (bulk) density and volumetric instability, evaluated with Brazilian standard NBR 11582:2012 [27]. Notice that the slag did not show expansion, but it was only evaluated until $7^{\text {th }}$ day.

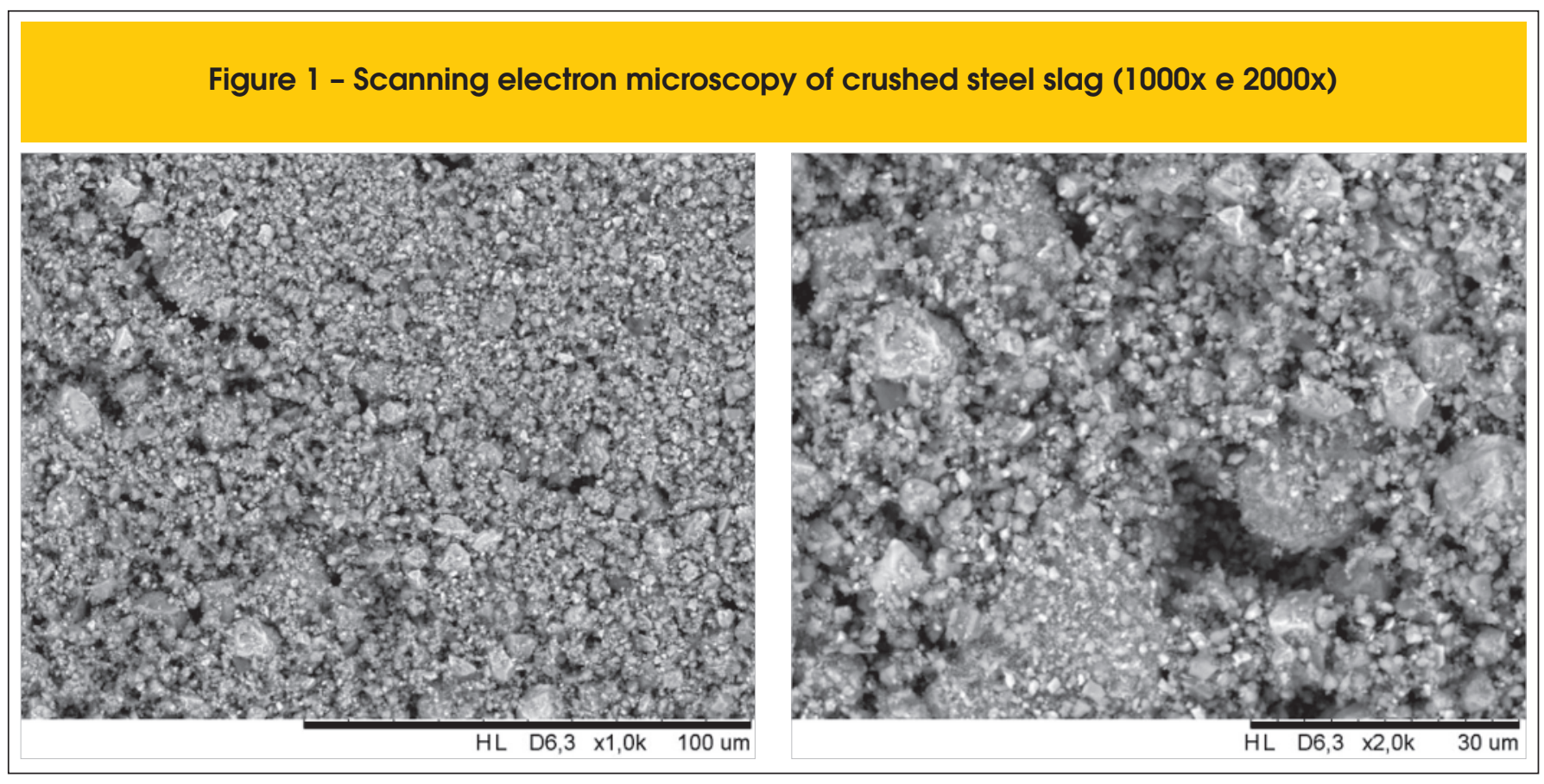




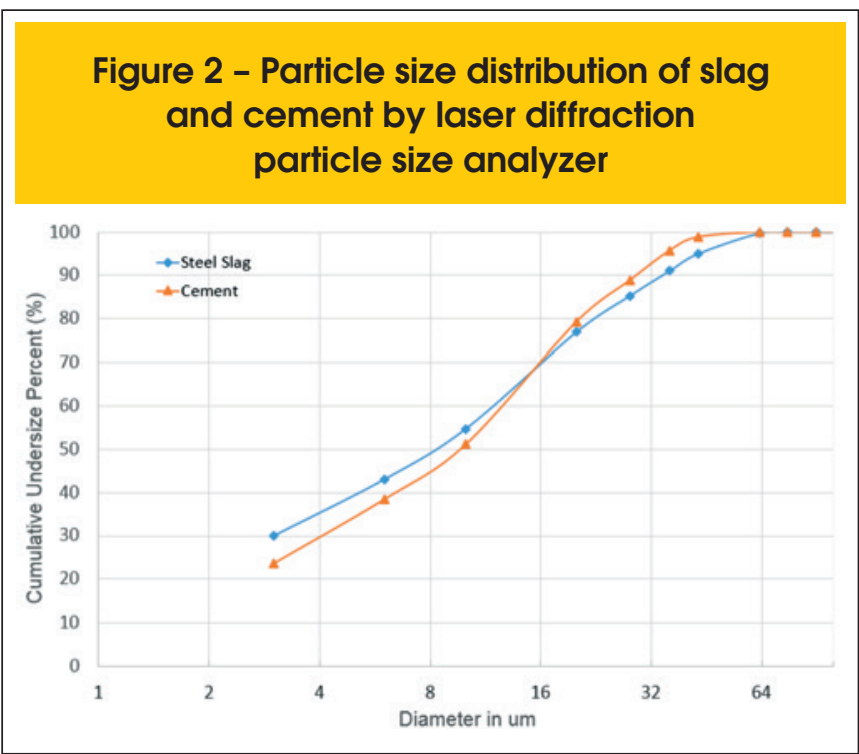

Following NBR 15577:2008, parts 4 and 5, three mortar bars $(25 \pm 0,7 \mathrm{~mm}$ by $25 \pm 0,7 \mathrm{~mm}$ by $285 \mathrm{~mm}$ ) were cast for each mixture, with mix design by mass of 1 part of cement, 2.25 parts of selected aggregate (either fine grained basalt or standard sand), and water/
Table 3 - Steel slag chemical composition by $X$-ray fluorescence spectrometer

\begin{tabular}{|c|c|}
\hline Chemical composition & Results \\
\hline $\mathrm{Fe}_{2} \mathrm{O}_{3}(\%)$ & 30.7 \\
\hline $\mathrm{SiO}_{2}(\%)$ & 24.1 \\
\hline $\mathrm{CaO}(\%)$ & 21.3 \\
\hline $\mathrm{Al}_{2} \mathrm{O}_{3}(\%)$ & 7.0 \\
\hline $\mathrm{MgO}(\%)$ & 6.3 \\
\hline $\mathrm{MnO}(\%)$ & 4.0 \\
\hline $\mathrm{Cr}_{2} \mathrm{O}_{3}(\%)$ & 1.1 \\
\hline $\mathrm{TiO}_{2}(\%)$ & 0.9 \\
\hline P2O5 (\%) & 0.5 \\
\hline $\mathrm{Na}_{2} \mathrm{O}(\%)$ & 0.4 \\
\hline $\mathrm{K}_{2} \mathrm{O}(\%)$ & 0.4 \\
\hline $\mathrm{SO}_{3}(\%)$ & 0.4 \\
\hline $\mathrm{BaO}(\%)$ & 0.4 \\
\hline $\mathrm{V}_{2} \mathrm{O}_{5}(\%)$ & 0.1 \\
\hline $\mathrm{SrO}(\%)$ & 0.1 \\
\hline $\mathrm{ZrO}_{2}, \mathrm{Nb}_{2} \mathrm{O}_{5^{\prime}}, \mathrm{ZnO}, \mathrm{Cl}(\%)$ & $<0.1$ \\
\hline Basicity & 1.85 \\
\hline Free $\mathrm{CaO}$ & 0.97 \\
\hline
\end{tabular}

\section{Figure 3 - Steel slag diffractogram}
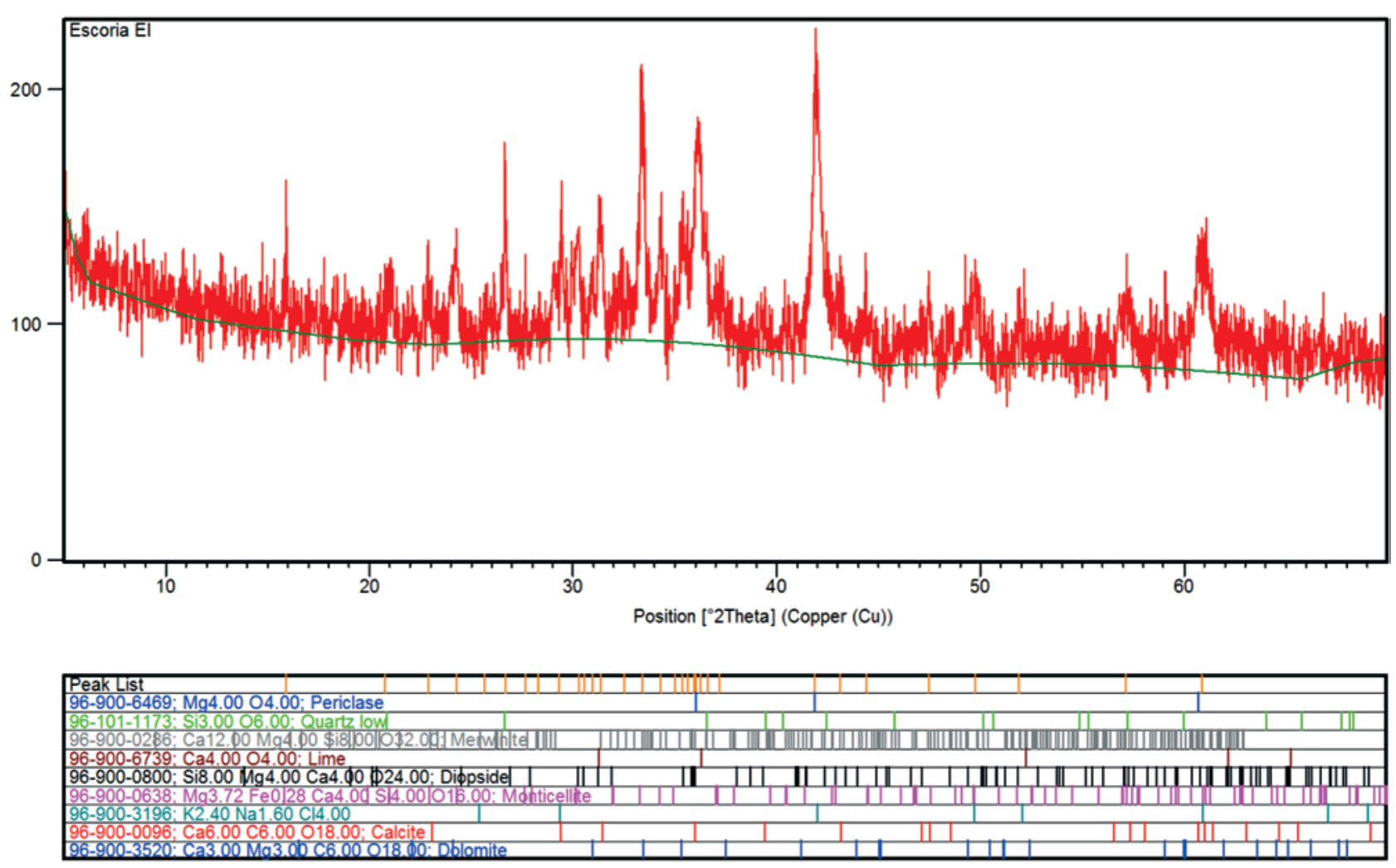


\begin{tabular}{|cc|}
\hline \multicolumn{2}{|c|}{$\begin{array}{c}\text { Table 4 - Steel slag } \\
\text { characteristics }\end{array}$} \\
\hline Property & Steel slag \\
\hline Apparent (bulk) density & $3.76 \mathrm{~g} / \mathrm{cm}^{3}$ \\
Expansibility (NBR 11582) & $0 \mathrm{~mm}$ \\
\hline
\end{tabular}

binder ratio of 0.47 . Twelve different mixtures were prepared containing $0,10,20$ and $30 \%$ by mass replacement of cement by slag. Three mortars were mixed without reactive aggregate and without slag, only with standard sand and Portland cement, for reference. The cement replacement ratio is shown in Table 5.

The specimens were cured in a moisture room for a period of 24 hours. After that, mortars received identification tags and the initial length of each specimen was measured. The specimens were then stored in a climatic chamber with temperature of $80^{\circ} \mathrm{C}$ immersed in distilled water. After another measurement was taken, the specimens were immersed in a $1 \mathrm{~N}$ sodium hydroxide $(\mathrm{NaOH})$ solution, at a temperature of $80^{\circ} \mathrm{C}$. Expansion rate is increased due temperature, while the sodium hydroxide solution provides enough alkaline ions. Following NBR 15577:2008, the specimens were measured at $8,16,22$ and 30 days.

\section{Results and discussion}

Figure 4 presents the average expansion measured in all specimens. The relative expansion is obtained by the following expression:

$$
\mathrm{R}=100 \frac{\mathrm{E}_{4}-\mathrm{E}_{5}}{\mathrm{E}_{4}}
$$

where $R$ is the percentage reduction of mortar expansion, $E_{4}$ is the average expansion of the mortar without mineral addition (without slag - \%) and $E_{5}$ is the average expansion of mortars with mineral addition (\%). Results are presented in Figure 5.

Figures 4 and 5 show that slag was able to reduce expansion due AAR. Nevertheless, it should be employed with caution. Good reduction is achieved with $20 \%$ of cement replacement by slag, with expansion of $0.12 \%$ at 16 days and $0.15 \%$ at 30 days.

According to NBR 15577-1:2008, a mineral addition is considered

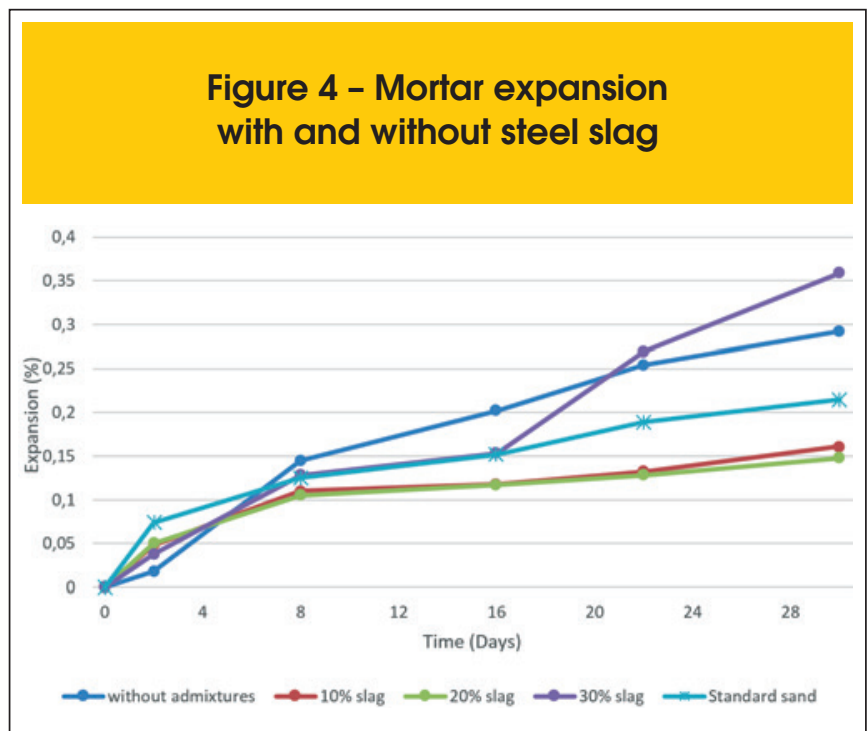

effective only if expansion is under $0.10 \%$ at 16 days, which was not attained by any of the proposed replacements. It worth notice, nevertheless, that the expansion was reduced about $40 \%$, as seen in Figure 5. Probably the basaltic aggregate is highly reactive to

\section{Figure 5 - Percentage reduction $(R)$ of mortar expansion, related to mortar without slag}

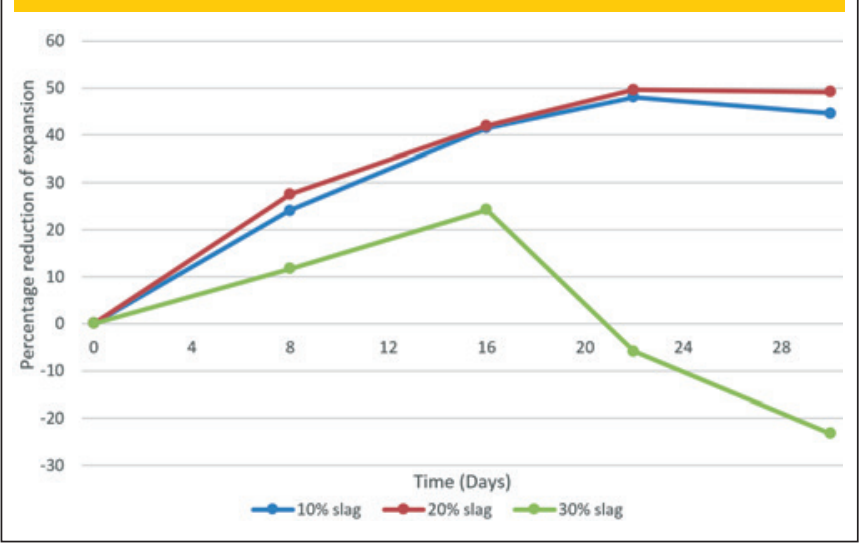

\section{Table 5 - Cement replacement ratio}

\begin{tabular}{|c|c|c|c|c|}
\hline \multirow{2}{*}{ Replacement ratio } & \multicolumn{2}{|c|}{1} & \multirow{2}{*}{$\begin{array}{c}2.25 \\
\text { Aggregate (g) }\end{array}$} & \multirow{2}{*}{$\begin{array}{c}0.47 \\
\text { Water (g) }\end{array}$} \\
\hline & Cement (g) & Slag (g) & & \\
\hline 0\% (Reference) & 146.67 & - & 330.00 & 68.93 \\
\hline $10 \%$ & 132.00 & 14.67 & 330.00 & 68.93 \\
\hline $20 \%$ & 117.34 & 29.33 & 330.00 & 68.93 \\
\hline $30 \%$ & 102.66 & 44.01 & 330.00 & 68.93 \\
\hline Sand (no reactive) & 146.67 & - & 330.00 & 68.93 \\
\hline
\end{tabular}




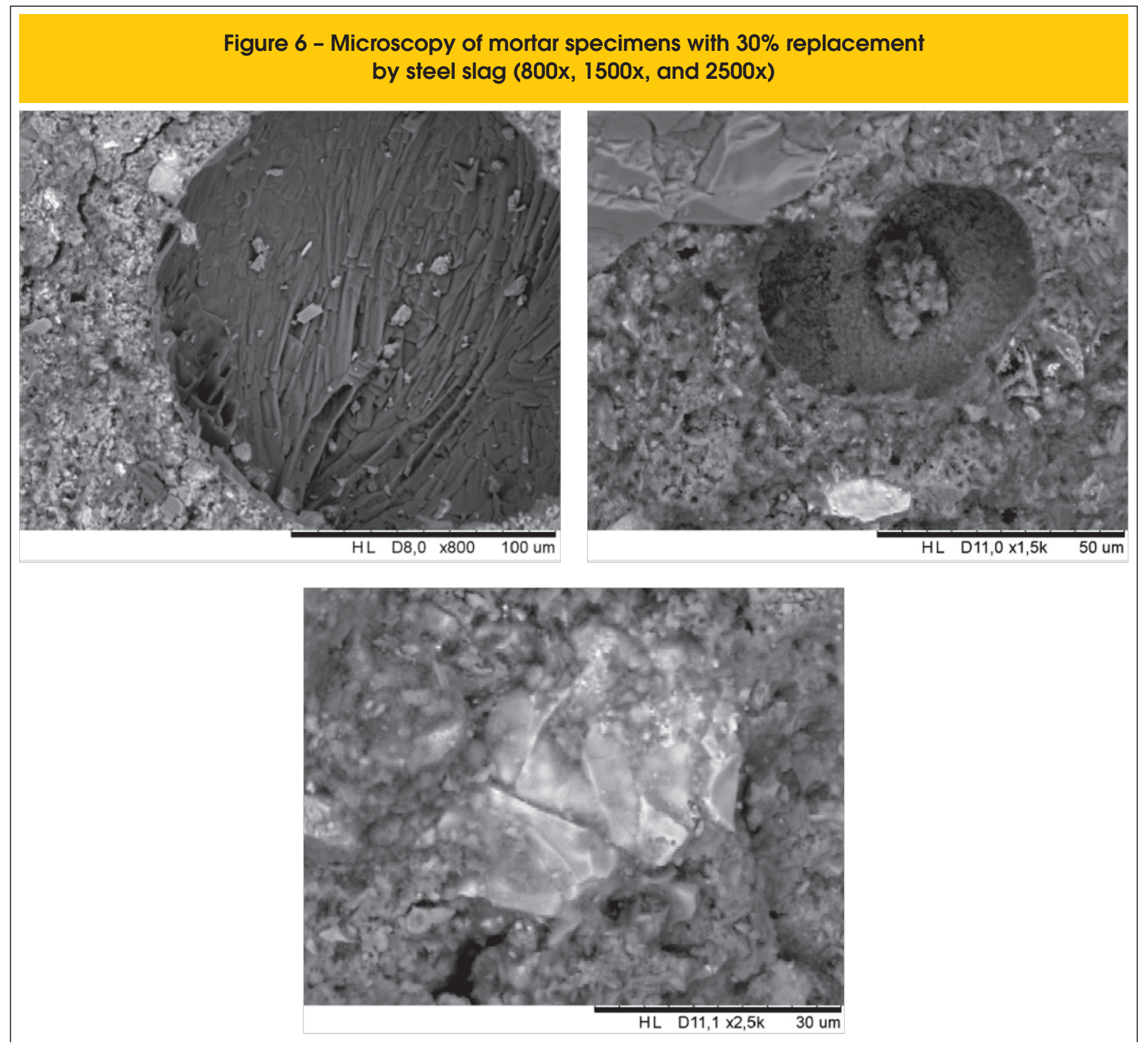

alkalis, and it might be interesting to test the replacement with a less reactive aggregate, as stated by the Brazilian standard.

It is also worth point out that the expansion in mortar with $30 \%$ of cement replacement by slag was reduced about $25 \%$ at 16 days, but expansion is observed after 30 days. Figure 6 shows a scanning electron microscopy made in a mortar with $30 \%$ of cement replacement. The first and second sub-image, with zoom of $800 x$ and $1500 x$, show a slag grain, with reaction rim. The third sub-image shown an aggregate grain, with no reaction rim, indicating that the reaction is probably restrained, maybe even suppressed. Latter expansion could then be caused by free calcium oxide [20].

A point to be clarified remains, in which the excess calcium rather than assist in expansion as would be expected (see [21] for example), reduced the alkali-aggregate reaction.

\section{Conclusions}

Evaluation of the effectiveness of the use of steel slag in reducing expansion due to alkali-aggregate reaction has been studied. The fine grained basalt with volcanic glass scattered throughout the rock was highly reactive, with expansion of $0.86 \mathrm{~mm}(0.29 \%)$ at 30 days in the accelerated mortar-bar test set by Brazilian standard NBR 15577:2008.

Regarding the steel slag addition, it is observed that at 16 days there was significant reduction in the mortar expansion due AAR with $10 \%$ and $20 \%$ of cement replacement, setting almost $54 \%$ of expansion reduction. Despite it, expansion is above the limit of $0.10 \%$ set by Brazilian standard NBR 15577:2008. Furthermore, expansion still develops the end of the measurement, at 30 days, which implies that the reason behind expansion is still there. 
It has been considered that the reason for the expansion is the excess of free calcium oxide and magnesium oxide, since no reaction rim or gel bags were observed in the specimens with 10,20 or $30 \%$ of cement replacement by steel slag.

In this sense, we conclude that a steel slag with high content of calcium oxide $(\mathrm{CaO})$ may have opposite effect to the expected, which may mitigate AAR yet expansion still develop due the presence of free calcium oxide and magnesium oxide.

\section{Acknowledgment}

Authors acknowledge UTFPR-PB for financial support and LAC TEC - Institute of Technology for Development by providing the reactive aggregate. We also acknowledge prof. Dr. Caroline Angulski da Luz for the assistance in the analysis of X-ray diffraction and laser diffraction particle size analyzer.

\section{Bibliography}

[1] Pan, J. W.; Feng, Y. T.; Wang, J. T.; Sun, Q. C.; Zhang, C. H.; Owen, D. R. J. Modeling of alkali-silica reaction in concrete: a review. Frontiers of Structural and Civil Engineering, v.6, n.1, 2012; p.1-18.

[2] Tiecher, F. Influence of the crystallinity and deformation of quartz on alkali-aggregate reaction - in portuguese. Ph.D. Thesis, Federal University of Rio Grande do Sul, Porto Alegre, 2010.

[3] Couto, T. A. Alkali-aggregate reaction: a study of the phenomenon in siliceous rocks - in portuguese. Master thesis, Federal University of Goiás, Goiânia, 2008.

[4] Collins, R. J.; Bareham, P. D. Alkali-silica reaction: suppression of expansion using porous aggregate. Cement and Concrete Research, v.17, n.1, 1987; p.89-96.

[5] Ducman, V.; Mladenovic, A.; Suput, J. S. Lightweight aggregate based on waste glass and its alkali-silica reactivity. Cement and Concrete Research, v.32, n.2, 2002; p.223-226.

[6] Jensen, A. D.; Chatterji, S.; Christensen, P.; Thaulow, N.; Gudmundsson, H. Studies of alkali-silica reaction. Part 1: a comparison of two accelerated test methods. Cement and Concrete Research, v.12, n.5, 1982; p.641-647.

[7] Qinghan, B.; Nishibayashi, S.; Xuequan, W.; Yoshino, A.; Hong, Z.; Tiecheng, W.; Mingshu, T. Preliminary study of effect of LiNO2 on expansion of mortars subjected to alkalisilica reaction. Cement and Concrete Research, v.25, n.8, 1995; p.1647-1654.

[8] Lumley, J. S. ASR suppression by lithium compounds. Cement and Concrete Research, v.27, n.2, 1997; p.235-244.

[9] Diamond, S. Alkali Silica Reactions - some paradoxes. Cement and Concrete Composites, v.19, n.5-6, 1997; p.391401 ;

[10] Mo, X.; Jin, T.; Li, G.; Wang, K.; Xu, Z.; Tang, M. Alkali-aggregate reaction suppressed by chemical admixture at $80 \mathrm{oC}$. Construction and Building Materials, v.19, 2005; p.473-479.

[11] Diamond, S. Unique response of LiNO3 as an alkali silica reaction-preventive admixture. Cement and Concrete Research, v.29, n.8, 1999; p.1271-1275.

[12] Qian, G.; Deng, M.; Tang, M. Expansion of siliceous and dolomitic aggregates in lithium hydroxide solution. Cement and Concrete Research, v.32, n.5, 2002; p.763-768.
[13] Silva, D. J. F. Study of effects of lithium nitrate on expansion of mortars subjected to alkali-silica reaction - in portuguese. Master thesis, São Paulo State University, Ilha Solteira, 2007.

[14] Monteiro, P. J. M.; Wang, K.; Sposito, G.; Santos, M. C.; Andrade, W. P. Influence of mineral admixtures on the alkaliaggregate reaction. Cement and Concrete Research, v.27, n.12, 1997; p.1899-1909.

[15] Bijen, J. Benefits of slag and fly-ash. Construction and Building Materials, v.10, n.5, 1996; p.309-314.

[16] Munhoz, F. A. C. Effect of mineral admixtures in controlling the alkali-silica reaction and alkali-silicate reaction - in portuguese. Master Thesis, Polytechnic School of the University of São Paulo, São Paulo, 2007.

[17] Silveira, A. A. Contribution to the study of rice husk ash admixtures on concretes submitted to alkali-agreggate reactions - in portuguese. Ph.D. Thesis, Federal University of Rio Grande do Sul, Porto Alegre, 2007.

[18] Ramachandran, V. S. Alkali-aggregate expansion inhibiting admixtures. Cement and Concrete Composites, v.20, n.2-3, 1998; p.149-161.

[19] Masuero, A. B.; Dal Molin, D. C. C.; Vilela, A. C. F. Stabilization and technical feasibility of electric steel slag - in portuguese. Ambiente Construído (On-line), v.4, n.2, 2004; p.57-81.

[20] Hermann, A.; Souza, L.; Luz, C. A.; Pereira Filho, J. I. Valorização da escória de aciaria em cimentos aluminosos e cimento Portland. In: Encontro Latino-americano sobre Edificações e Comunidades Sustentáveis, Vitória-ES, 2011.

[21] Lindgard, J.; Andiç-Çakir, O.; Fernandes, I.; Ronning, T. F.; Thomas, M. D. A. Alkali-silica reactions (ASR): Literature review on parameters influencing laboratory performance testing. Cement and Concrete Research, v. 42, 2012; p.223243.

[22] Luxaân, M. P.; Sotolongo, R.; Dorrego, F.; Herrero, E. Characteristics of the slags produced in the fusion of scrap steel by electric arc furnace. Cement and Concrete Research, v. 30, 2000; p. 517-519.

[23] Tsakirids, P. E.; Papadimitriou, G. D.; Tsivilis, S.; Koroneos, C. Utilization of steel slag for Portland cement clinker production. Journal of Hazardous Materials, v. 152, 2008; p. 805-811.

[24] Qiang, W.; Peiyu, Y. Hydration properties of basic oxygen furnace steel slag. Construction and Building Materials, v. 24, 2010; p. 1134-1140.

[25] Xuequan, W.; Hong, Z.; Xinkai, H.; Husen, L. Study on steel slag and fly ash composite Portland cement. Cement and Concrete Research, v. 29, 1999; p. 1103-1106.

[26] Brazilian Technical Standards Association. Aggregates: Alkali-aggregate reactivity. NBR 15577, Rio de Janeiro, 2008.

[27] Brazilian Technical Standards Association. Portland cement - Determination of soundness by the Le Chatelier method Method of test. NBR 11582, Rio de Janeiro, 2012.

[28] Intituto de Pesquisas Tecnológicas. Brazilian standard sand. In: < http://www.ipt.br/solucoes/255.htm> 